\title{
A Pragma-Semantic Study of Language of Conflict: Gowon and Ojukwu Pre-Civil War Speeches in Focus
}

\author{
Timothy Adeyemi Akanbi \\ Department of Linguistics and Nigerian Languages, Ekiti State University, Ado-Ekiti, Nigeria \\ Email: yemiakanbi@gmail.com, timothy.akanbi@eksu.edu.ng
}

How to cite this paper: Akanbi, T. A. (2019). A Pragma-Semantic Study of Language of Conflict: Gowon and Ojukwu Pre-Civil War Speeches in Focus. Open Journal of Modern Linguistics, 9, 354-364. https://doi.org/10.4236/ojml.2019.95029

Received: August 27, 2019

Accepted: October 9, 2019

Published: October 12, 2019

Copyright (อ 2019 by author(s) and Scientific Research Publishing Inc. This work is licensed under the Creative Commons Attribution International License (CC BY 4.0).

http://creativecommons.org/licenses/by/4.0/ (c) (i) Open Access

\begin{abstract}
Language is a vital instrument used by human beings to disseminate information to the understanding of people. The way language used usually determines the consequence or outcome of its impact on the society. Through language, conflict that could result in war can be engendered; and also through language, peace in the society can be promoted. Depending on how language is used, the experience within the society can be negative or positive. In this paper, the speeches of Lt. Col. Gowon and Lt. Col. Ojukwu (as they then were in pre-1966) preceding the civil war in Nigeria are in focus. The various ways these leaders subtly presented their speeches raised tension and eventually led to the civil war which was fought for more than three years. In the study, it was argued that if the two leaders have been more circumspect in their use of language, probably, the war that ravaged Nigeria for more than three years would have been averted. The paper concludes that leaders should always explore peaceful means through their use of language during volatile situation so that the sentiments of their followers will not be wiped up.
\end{abstract}

\section{Keywords \\ Conflict, Civil War, Citizens, Arrowhead}

\section{Introduction}

Language is a veritable tool given to homo-sapiens. It is language that differentiates human beings from animals. This assertion follows (Fromkin et al., 2011: p. 1) that: "The possession of language, perhaps more than any other attribute, distinguishes humans from other animals. As a social behavior, language is a key element in defining humans as social beings." As a species, our cumulative abili- 
ty to use language to communicate with each other creates, shares, and preserves the nature of the social interactions that make up our various cultures and norms (McLaughlin, 2006: p. 6). To understand our humanity, one must understand the nature of language that makes us human. Language, therefore, is a vital instrument which aids the communicative ability of the members of any given society or geographical territory. (Mey, 2006: p. 6) while talking about the communicative importance of language says that "communication in society happens chiefly by means of language. However, the users of language, as social beings, communicate and use language, on society's premises; society controls their access to the linguistic and communicative means." Language use can be pragmatic in nature. Pragmatics, as the study of the way human beings use language in communication, bases itself on a study of those premises and determines how they affect, and effectualize, human language use. Consequently, the choice of language in a particular situation will either engender peace or cause conflict. The language chosen will either enhance brotherhood or enmity. It is important to note that the choice and meaning of the way communication is weaved through the use of language which will dictate the meaning that will be associated with it. In some instances, the language used in communication may have a straightforward meaning, it may be misinterpreted and it may be pragmatic in nature. It should also be noted that since language is a human phenomenon and human beings inhabit societies, the study of language use in any given society and in any given situation and within the context it is used, cannot be jettisoned. This is why pragmatics captures how language is used in a particular social context and how meaning can be extracted from its use (Odebode \& Oluwabukola, 2015: p. 1). Language use goes beyond just speaking; it involves a kind of background knowledge of the speaker/hearer. Mey (ibid) opines that "Pragmatics studies the use of language in human communication as determined by the conditions of society." This paper therefore, looks at the pragmatic/semantic analysis of speeches of Gowon and Ojukwu the two protagonists of the civil war that ravaged Nigeria between 1967 and 1970. Though, there are many other people whose speeches were significant during the period of the Nigeria civil war, these two personalities were chosen for discussion in this paper because they were the leaders of both sides of the divide during the period of the civil war. Why Gowon was the Military Head of State of Nigeria, Ojukwu was the leader in Biafra. It is also pertinent to say that the speeches of these two leaders carried more weight than any other speeches of other people during the period; no matter how important such personality might be.

\section{The Story of Civil War in Nigeria}

Many books have been written about the history of Nigeria as a nation. Some have been written out of sentiment while some are written out of genuine interest for the country. In the same vein, many books have been written on the civil war in Nigeria where the events that culminated into the battle have been told. 
The story of Nigeria Civil War did not just start as a result of the January 1966 coup, it was a build-up of different activities from the past up to the time the war actually broke out. As Obasanjo in his book My Command puts it; he says that until 1900, the land mass known today as Nigeria existed as a number of independent and sometimes hostile national states with linguistic and cultural differences. For this reason, according to Obasanjo, Sir Hugh Clifford described Nigeria as 'a collection of independent Native States, separated from one another by great distances, by difference of history and traditions and by ethnological, racial, tribal, political, social and religious barriers. Despite all this background information, known to the colonial masters, they still went ahead to amalgamate these unrelated units of land mass and made them one country. In doing this, one part of this land mass was favoured at the detriment of the other parts. Thus, the seed of discord was sown right from the inception of the country.

Because of the failure of the British Government to understand the nature of the different nations they have amalgamated, every step taken by the colonial masters and the nationals themselves after the Nigeria independent always ended in conflict. This issue was acknowledged in 1967 by the then military government when they say (quoting from Obasanjo, 1980, 2015) that:

In our common desire to win independence, many vital problems were left unresolved. One of these outstanding problems was the creation of more states which would have provided a more lasting foundation for stability of the Federation of Nigeria. The British Government pointed out at the time that if new states were to be created, the new states must be given at least two years to settle down before independence could be granted. On reflection, Nigerian leaders have admitted that the British were right and they were wrong on this vital issue in hurrying to independence without solving the problem of stability of the Federation.

This unresolved problem noted by the military government together with many more others, resulted into the various incessant clashes being witnessed in Nigeria from then up till now. The crisis that erupted in the Western Region among the Action Group, which led to the detention of many of the leaders of the party including Chief Obafemi Awolowo, the Leader of Opposition, was one of the crises that arose as an offshoot of the problems created by the British before handing over independence to Nigeria. The final straw that broke the camel's back was the election of 1965 in the Western Region. This election was brazenly manipulated and rigged. In recollecting this issue, (Obasanjo, 2015) has this to say:

Maturity and good sense prevailed to ward off the disruption imminent after the 1964 general election. The same could not be said of the Western Regional Election of 1965. The rigging and irregularities in this election were alleged to have been more brazen and more shameful. Law and order broke down completely, leading to an almost complete state of anarchy. Arson and indiscriminate killings were committed by a private army of tugs. Law abiding citizens lived in constant fear for their lives and property. 
This was the state of affairs when the coup of 15 January 1966 took place.

The coup that was staged by the so called five majors was partly successful and partly unsuccessful. It was successful because it led to the change of government from the civil government to the military government and it also led to the stoppage of the hostilities particularly in the Western Region. It was a failure because those that staged the coup were not the beneficiary of it. Major General Aguiyi Ironsi, who never participated in the carrying out of the coup and who never prepared for any role in governing Nigeria, became the Military Head of State. His actions which are wrong steps in the wrong direction and his inactions on vital issues culminated in the second coup d'état. These various actions and inactions led to the Nigeria civil war which eventually broke out.

\section{Theoretical Framework}

The framework for this study is the Speech Act Theory. This term is used in most cases as a technical term in linguistics and philosophy of language. Speech Act is a theory that captures an action performed by someone through his words. The British philosopher J. L. Austin (1962) who was the author of the theory connects the term to pragmatics. He claims that, through a person's speech, he performs an act, or does something which may be a statement, prediction, or warning and that meaning is found in what an expression does. By simple deduction, the core aspect of the Speech Act Theory is that an utterance is part of an action within the framework of social institution and conventions. Austin then, puts forward three strata of speech acts: locutionary act, illocutionary act and perlocutionary act. A locutionary act is the actual utterance and its ostensible meaning, comprising phonic, phatic and rhetic acts which actually correspond to the verbal, syntactic and semantic aspects of any meaningful utterance. He opines that a phonic act produces an utterance-inscription. This utterance-inscription is concerned with physical act of producing a certain sequence of vocal sounds (in the case of spoken language), or a set of written symbols (in the case of written language). And that of phatic act is an act of composing a particular linguistic expression in a particular language. It is the act of constructing a well formed string of sounds/symbols (a word, phrase, or sentence in a particular language). He goes further to say that Rhetic act is an act of contextualising the utterance-inscription (Austin, 1962). This kind of act, according to him, is responsible for tasks such as assigning reference, resolving deixis, and disambiguating the utterance-inscription lexically and grammatically. By the illocutionary act, Austin believes that saying is doing. An interesting type of illocutionary act is that performed in the utterance of what Austin calls performatives. In explicit cases of performative sentences, the action that the sentences describe (demanding, ensuring) are performed by the utterance of the sentences themselves. Stating this theory further, Austin explains that perlocutionary acts entail the consequences, outcomes or effects of utterances on the audience in a linguistic encounter. Its actual effect, such as persuading, convinc- 
ing, scaring, enlightening, inspiring, or otherwise can get someone to do or realize something, whether intended or not (Austin, 1962). For instance, the locution "See a snake behind you" has an illocutionary act of informing or warning. The perlocutionary act will be manifested in the addressee who either runs or screams or faints as a consequence or outcome of the warning.

\section{Data Analysis}

Here in this section, we shall explore and apply the speech act theory on the data presented. Each datum which is in speech form will go along the speech act principle as put forward by (Austin, 1962). This is with a view to underscore its presupposition, inference and implicature in order to account for its total meaning. Presupposition, in pragmatics, is an assumption about the world whose truth is taken for granted in discourse. For instance, in an utterance "you have started again" implies that the actor has been warned of such act sometime before the present one. Therefore, in line with (Yule, 1985: p. 132) supposition, "What a speaker assumes is true or is known by the hearer can be described as a presupposition". On this, inference which is the activity performed by a reader or interpreter in drawing conclusions that are not explicit in what is said can be appealed to. In consequence of this, Levinson (1983, 2005: pp. 13-14) views it as meaning components which are context dependent. One other concept we shall use in analyzing our data is what is known as implicature. This is a technical term which is introduced into pragmatics by (Grice, 1975) for accounting for the implications of an utterance that goes beyond what is strictly implied by the content of the utterance; or a violation of any of the conversational maxims (see Grice, 1975). The analysis of this study is not only going to be based on pragmatics alone, the semantics aspect is also going to be focused. There has been controversy on the issue of the relatedness of pragmatics and semantics. The issue is whether semantics and pragmatics are one and the same or whether they are distinct. (Leech, 1983), as explained by (Mey, 2006) distinguishes between three possible ways of structuring this relationship; semanticism (pragmatics inside semantics), pragmaticism (semantics inside pragmatics) and complementarism (semantics and pragmatics complement each other, but are otherwise independent areas of research). Using all these as background, we shall carry out the analysis of our data in the immediately following section.

\section{Analysis of War Speeches of Ojukwu and Gowon}

In many instances, war does not just break out; it comes up as a result of series of words that are uttered by the protagonists. In the case of the Nigeria Civil War, the outbreak was as a result of various utterances from people especially the opinion leaders of the people. For instance, at a point before the war broke out, some people are saying that the first coup was an Ibo coup. The carriers of this statement forgot that the leader of that coup, even though of Igbo extraction, was from Midwest Nigeria. Two of the participants were also not of Igbo origin. 
Only two out of the three coup plotters are actually core Igbo persons. Those who lost their lives both in the army and politics did not also help matters; it corroborated the saying of those who were ready to foment trouble. For instance, no Ibo person, whether in the army or among the politicians was killed. However, those who were killed were not the focus of this paper; our focus is on the utterances of the people and their leaders. It was this kind of tagging the coup as an Ibo one that whipped up sentiment in some parts of Northern Nigeria which resulted into what the Igbo people termed as pogrom or ethnic cleansing. The action in the north is viewed as a selective killing of some particular ethnic extractions. The consequence of this was that the Igbo people fled the Northern part of Nigeria in en masse to come to the Eastern Nigeria leaving their property and belongings behind.

In his speech to the National Reconciliation and Peace Committee in Enugu in May 1967, Ojukwu said:

I started off this struggle in July 1966 with 120 rifles to defend the entirety of the East. I took my stand knowing fully well that doing so, whilst carrying my name in history; I was signing also my death warrant. But I took it because I believe that this stand was vital to the survival of the South. I appealed for settlement quietly because I understood that this was a naked struggle for power and that the only time we can sit down and decide the future of Nigeria on the basis of equality will be equality of arms. Quietly I built. If you do not know it, I am proud and my officers are proud that here in the East, we possess the biggest Army in Africa. I am no longer speaking as an under-dog. I am speaking from a position of power; it is not my intention to unleash the destruction which my Army can unleash. It is not my intention to fight unless I am attacked. If I am attacked, I will take good care of the aggressor. (Culled from Obasanjo, 1980: p. 22).

Perusing this speech by Ojukwu superficially, one may not notice the pragmatic and social implication of it. The speech has many social and pragmatic consequences. Here, Ojukwu is subtly calling his people out for war. The sociological essence of this speech is that his people were already distressed because of the various ugly experiences they have passed through in their original place of abode i.e. the Northern part of Nigeria; any statement that could push them further is what they needed. Ojukwu, knowing this capitalized on such experience. The pragmatic point here is that those Ojukwu was addressing as well as the Igbo people knew the situation on ground, they knew the background of the whole thing, therefore, his speech will be meaningful to them (without any further explanation) more than to somebody who is not part of the society affected by the adverse situation.

The first line of the speech above is also very significant and relevant to our analysis. By saying that he "started off the struggle ... with 120 rifles to defend the entirety of the East" shows him as a bold and courageous man. If he could be willing to lay down his life for the survival of his people, every member of his ethnic group will be ready to follow suit. More so, if he could build with 120 
rifles to the level he was as at the time he was delivering his speech, no one will have any doubt about his ability to carry his people through. This, his army and the citizens understood. His speech was not to dissuade his hearers from engaging in war, it is a call to battle. By saying that "...it is not my intention to unleash the destruction which my Army can unleash" connotes that no army can defeat his army. By this, he is instilling confidence in his own army that they are formidable and impregnable. Finally, on this speech, we see an indication, though subtly, of imminent of war. The speech is either calling for war or calling his people to prepare for war. By saying that "it is not my intention to fight unless I am attacked," is a kind of euphemism. There is the evidence that he has prepared for war eventuality. He made this clear by saying that "If I am attacked, I will take good care of the aggressor." The taking good care here is not a kind of offering an olive branch but that he was ready to pay the aggressors in their own coin. Therefore, the concept 'good' does not carry the general meaning but a hidden meaning of unleashing terror on his enemies.

Still analyzing Ojukwu's war speeches further, we look at his speech in declaring Eastern Region as an independent and autonomous country and observe some socio-pragmatic meaning in the speech.

Fellow countrymen and women, you, the people of Eastern Nigeria: Conscious of the supreme authority of Almighty God over all mankind, of your duty to yourselves and posterity; aware that you can no longer be protected in your lives and in your property by any government based outside Eastern Nigeria; believing that you are born free and have certain inalienable rights which can best be preserved by yourselves; unwilling to be unfree partners in any association of a political or economic nature; rejecting the authority of any person or persons other than the Military Government of Eastern Nigeria to make any imposition of whatever kind or nature upon you; determined to dissolve all political and other ties between you and the former Federal Republic of Nigeria; prepared to enter into such association, treaty or alliance with any sovereign state within the former Federal Republic of Nigeria and elsewhere on such terms and conditions as best to subserve your common good; affirming your trust and confidence in me; having mandated me to proclaim on your behalf, and in your name, that Eastern Nigeria be a sovereign independent republic, now, therefore, I, Lieutenant-Colonel Chukwuemeka Odumegwu Ojukwu, Military Governor of Eastern Nigeria, by virtue of the authority, and pursuant to the principles, recited above, do hereby solemnly proclaim that the territory and region known as an called Eastern Nigeria together with her continental shelf and territorial waters shall henceforth be an independent sovereign state of the name and title of "The Republic of Biafra." And I do declare that all political ties between us and the Federal Republic of Nigeria are hereby totally dissolved; all subsisting contractual obligations entered into by the Government of the Federal Republic of Nigeria or by any person, authority or organization or government acting on its behalf, with any person, authority 
or organization operating or relating to any matter or thing, within the Republic of Biafra, shall henceforth be deemed to be entered into with the Military Governor of the Republic of Biafra for and on behalf of the Government and people of the Republic of Biafra, and the covenants thereof shall, subject to this Declaration, be performed by the parties according to their tenor; all subsisting international treaties and obligations made on behalf of eastern Nigeria by the Government of the Federal Republic of Nigeria, shall be honored and respected; Eastern Nigeria's due share of all subsisting international debits and obligations entered into by the Government of the Federal Republic of Nigeria on behalf of the Federation of Nigeria shall be honored and respected; steps will be taken to open discussions of the question of Eastern Nigeria's due share of the assets of the Federation of Nigeria and personal properties of the citizens of Biafra throughout the Federation of Nigeria; the rights, privileges, pensions, etc. of all personnel of the Public Services, the Armed Forces and the Police now serving in any capacity with the Republic of Biafra, are hereby guaranteed; we shall keep the door open for association with, and would welcome any sovereign unit or units in the former Federation of Nigeria or in any other parts of Africa desirous of association with us for the purposes of running a common service organization and for the establishment of economic ties; we shall protect the lives and property of all foreigners residing in Biafra; we shall extend the hand of friendship to those nations who respect our sovereignty, and shall repel any interference in our internal affairs; we shall faithfully adhere to the charter of the Organization of African Unity and of the United Nations Organization; it is our intention to remain a member of the British Commonwealth of Nations in our right as a sovereign, independent nation. Long live the Republic of Biafra! And may God protect all who live in her!

https://www.vanguardngr.com/2017/05/ojukwu-1967-speech-that-called-for-s ecession-of-biafra

The above, which is part of the full speech of Ojukwu in declaring Eastern Nigeria as a sovereign state, is presented for analysis. Looking through the speech, certain meanings can be deduced from it. It is evident that Ojukwu was ready for any eventualities. He made this known by first curdling his people through this speech. He laid bare, what they stand to gain if they can stand, and stand alone. His speech starts with calling the attention of his people to what he wanted to say. The use of language here implies that he equaled himself with the people he was addressing when he says "fellow countrymen and women." By telling them what they stand to gain or lose by the action he has taken on their behalf has an inference. Though he did not tell them to take up arms and go for an attack, his intention is that they should be ready to go to war if the need arose. Ojukwu's reference to Nigeria as former republic of Nigeria is an indication that they were formally part of that territorial enclave but that now, Biafra is no more part of what is called Nigeria. 
In his speech after the second coup of 1966, Gowon gave a graphic picture of the situation of Nigeria as it was then. The excerpt of that speech as given on $31^{\text {st }}$ July, 1966 is presented below for analysis.

My fellow countrymen, the year 1966 has certainly been a fateful year for our beloved country, Nigeria. I have been brought to the position today of having to shoulder the great responsibilities of this country and the armed forces with the consent of the majority of the members of the Supreme Military Council as a result of the unfortunate incident that occurred on the early morning of $29^{\text {th }}$ July 1966.

...As a result of the recent events and the other previous similar ones, I have come to strongly believe that we cannot honestly and sincerely continue in this wise, as the basis of trust and confidence in our unitary system of government has not been able to stand the test of time. I have already remarked on the issues in question. Suffice to say that, putting all considerations to test-political, economic, as well as social-the base for unity is not there or is so badly rocked, not only once but several times. I therefore feel that we should review the issue of our national standing and see if we can help stop the country form drifting away into utter destruction. With the general consensus of opinion of all the Military Governors and other members of the Supreme and Executive Council, a decree will soon be issued to lay a firm foundation of this objective. Fellow countrymen, I sincerely hope we shall be able to resolve most of the problems that have disunited us in the past and really come to respect and trust one another in accordance with an all-round code of good conduct and etiquette.

...I am convinced that with your co-operation and understanding, we shall be able to pull the country out of its present predicament. I promise you that I shall do all I can to return to civil rule as soon as it can be arranged. I also intend to pursue most vigorously the question of the release of political prisoners. Fellow countrymen give me your support and I shall endeavour to live up to expectations. Thank you.

The speech of Gowon here started with an utterance that bothers on phatic communion. It is a way of giving the people a sense of belonging. The speech is pragmatic in nature and contains meanings that are not well defined. For instance, by saying that "the base for unity is not there or is so badly rocked, not only once but several times; I therefore feel that we should review the issue of our national standing and see if we can help stop the country form drifting away into utter destruction" implies that Nigeria should cease from being one country. However, only those that knew the background of the situation in the country could have an understanding of this nature. What is said here follows the notion of (Adegbija, 1988) where he opined that the scope of pragmatics can be viewed in five perspectives which include:

1) The message being communicated;

2) The participants involved in the message;

3) The knowledge of the world which they share; 
4) The deductions to be made from the text on the basis of the context;

5) The impact of the non-verbal aspect of interaction on meaning.

A close look at the datum above shows that it manifests these five perspectives. This is to say that the message being communicated is not one that indicates a peace period. The participants that form the audience were also aware of the situation in the country as at the period the message was being passed across. In addition, the one delivering the address and his audience share the same knowledge of the world that existed at the time. Through the context of the speech it was easy to deduce that the unity of the country is shaky. And finally what is not said in the speech can easily be added to it. Therefore, pragmatics has a lot of effect on the context within which any particular speech is being delivered.

\section{Conclusion}

We have so far in this study discussed the pragmatics of the Nigeria pre-civil war speeches of Yakubu Gowon and Odumegwu Ojukwu. We pointed out that the speeches were pragmatic in nature and were not geared towards dowsing the tension that was already pervasive. The speeches were void of explaining to the followers the ugly consequences of war neither were they persuading the people to tread the path of peace. They were a clarion call to war. It is important that those leading the people should always understand that the beginning of conflict is definitely always known, but when it will end is such that nobody can tell. There is also the damaging effect of war that should be considered before leaders start calling their followers out for war. What is normally destroyed during any conflict, either in a community or a nation could sometimes take several years to repair. In some instances, repairs may not even be possible.

\section{Conflicts of Interest}

The author declares no conflicts of interest regarding the publication of this paper.

\section{References}

Adegbija, E. F. (1988) A Speech Act Analysis of Consumer Advertisement. Bloomington, IN: Indiana University.

Austin, J. L. (1962). How to Do Things with Words. Oxford: Oxford University Press.

Fromkin, V., Rodman, R., \& Hyams, N. (2011). An Introduction to Language (9th ed.). Nashville, TN: Nelson Education, Ltd.

Grice, H. P. (1975). Logic and Conversation. In C. Peter, \& J. Morgan (Eds.), Syntax and Semantics (Vol. 3, pp. 41-58). New York: Academy Press.

Leech, G. N. (1983). Principles of Pragmatics. London: Longman.

Levinson, S. C. $(1983,2005)$. Pragmatics. Cambridge: Cambridge University Press.

McLaughlin, S. (2006). Introduction to Language Development (2nd ed.). New York:

Thomson Delmar Learning.

Mey, J. L. (2006). Pragmatics: An Introduction. London: Blackwell Publishers. 
Obasanjo, O. (1980, 2015). My Command. Lagos, Nigeria: Kachifo Ltd.

Odebode, I., \& Oluwabukola, D. (2015). Speech Acts in Billboard Messages of the Redeemed Christian Church of God, Redemption Camp, Nigeria: A Pragmatic Study. English Linguistics Research, 4, 17-23. https://doi.org/10.5430/elr.v4n2p17

Yule, G. (1985). The Study of Language. Cambridge: Cambridge University Press. 